\section{Need to lobby for access to}

\section{asthma medications}

$\mathrm{D}$ octors should unite to lobby governments to ensure that the increasing numbers of asthma and allergy sufferers have access to necessary medications, says Dr. Susan Waserman, past-president of the Canadian Society of Allergy and Clinical Immunologists.

Children with asthma have poorer health outcomes and quality of life when their families face financial hardships paying for prescription medication, either because of high copayments or lack of drug coverage, according to research presented at the 2nd annual AllerGen conference held in Hamilton, Feb. II to I3.

The conference addressed myriad issues including the cost of medication, the role of the environment, the rising incidence of food allergies and the genetic basis of asthma.

Multiple expensive medications are routinely prescribed for asthma, the most common chronic disease of childhood in developed countries. In Canada, almost $\mathrm{I}_{2} \%$ of children aged $\mathrm{I}_{2}-\mathrm{I} \mathrm{g}$ have asthma, 4 times the rate 2 decades ago. Food allergies have also risen dramatically during the same period, said Dr. Judah Denberg, scientific director of AllerGen, the Allergy, Genes and Environment Network Centre of Excellence, which was launched in 2005 and now includes 150 researchers.

Patients can't do without inhalers and epi-pens, but these medications can be quite expensive, notes Waserman, who is on an advisory committee for AllerGen. Epi-pens for allergic reactions cost about $\$$ I2O, while controller drugs for asthma cost about $\$ 60$ to $\$ 70$ for a month's supply.

Financially pressed parents often skip buying the more expensive controller medication and instead rely on less pricey symptom relievers for asthma, which should not be used regularly, said Wendy Unger, a scientist at the Hospital for Sick Children in Toronto.

New Ontario research shows that $21 \%$ of children and $24.6 \%$ of adults who end up at emergency wards because of asthma attacks have no drug

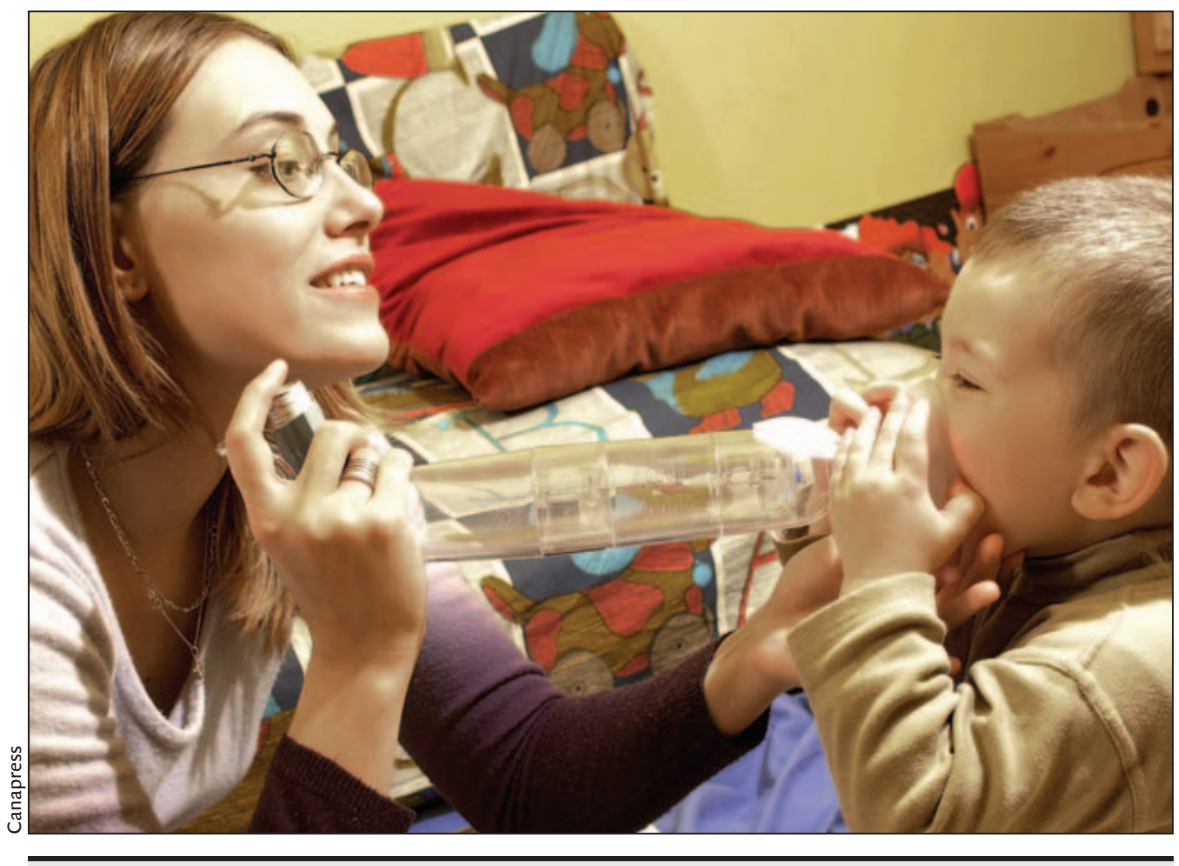

Nearly $12 \%$ of Canadian children aged $12-19$ have asthma -4 times the rate 2 decades ago.

plans, despite the fact that only about I0\% of Canadians have no drug coverage (Chest 2006;129:909-17).

In reviewing the widely varying rates of public drug plan coverage for children across Canada, Ungar noted that provinces don't agree on "the importance of providing comprehensive coverage for all children" and little attention has been paid to this vulnerable population. Ungar recommends that doctors consult with their patients about asthma drug costs before writing prescriptions.

Asthma symptoms can also be dramatically reduced when attention is paid to the home environment, according to a study by Dr. Tim Takero of Simon Fraser University. The study evaluated home interventions including providing special mattress covers and reducing the impact of mould, pets, roaches, tobacco smoke, mites and moisture (Am J Public Health 2005;95:652-9). "Housing is an important determinant of respiratory health... and improvements could have a major impact on asthma," said Takero, who recommended that government departments of health and housing be merged.

Outdoor air also has a clear impact. A California children's health study found a reduction in lung function in children living closest to highways, and several European studies have linked traffic with asthma, Dr. Jeff Brook of Environment Canada reported.

Anaphyalxis is also on the rise, though to date it has received less research attention than asthma. A Montréal public school study revealed, through testing, that $\mathrm{I} .5 \%$ of children were allergic to peanuts, Waserman noted ( $\mathrm{J}$ Allergy Clin Immunol. 2003; II2:I223-8). Meanwhile, a McGill University study found an annual incidence rate of II.I for accidental exposure to peanuts in a group of children with mild to severe peanut allergies $(J \mathrm{Al}$ lergy Clin Immunol. 2006;118:466-72).

Waserman stressed the need for people with food allergies to be seen by specialists because misdiagnosis and misinformation can affect a patient's quality of life. But for nonurgent cases, wait times for specialists can stretch over many months since only 129 allergy and immune disease specialists were practising in Canada in 2004 (I for every 247863 Canadians).

In other research, about 120 "susceptibility" genes have been associated with asthma, and 5 main candidate genes have been identified, AllerGen attendees learned. Asthma is a "really complex disease" and it is challenging to identify what genes and other processes are associated with it, said Yohan Bossé, a researcher at McGill University and the 
Genome Québec Innovation Centre. Bossé has found that mice bred without the vitamin D receptor fail to develop experimental allergic asthma.

Researchers are particularly keen to study the gene and environment interaction, which will likely provide some explanation for the rising rates of asthma and allergies; however, researchers acknowledge they need to know much more about both sides of the equation. - Ann Silversides, Toronto

DOI:I0.1503/cmaj.070404

\section{UK doctors may lose}

\section{self-regulation}

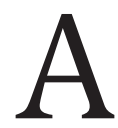
proposal from the United Kingdom Department of Health could bring an end to the era of professional self-regulation for doctors and other health professions by 2008 .

A Department spokesman said the question of self-regulation arose in response to the Harold Shipman Inquiry (CMAJ 2003;169:46I); several other high-profile cases; and the Chief Medical Officer's review of medical regulation, Good Doctors, Safer Patients (July 2006). The Department has now published its white paper: Trust, Assurance and Safety: The Regulation of Health Professionals in the 2Ist Century.

Parliament must pass a Bill before the proposals come into effect; to date the bill has not even been tabled.

The General Medical Council (GMC), charged with protecting the public and ensuring proper standards in medicine, submitted its proposal for change to the government in November 2006. "Regulation has been surrounded by controversy for the past decade, a situation that is not good for either public or professional confidence," Chief Executive, Finlay Scott told CMAJ.

If the proposal is approved, the regulators will be independent of government, and will consist of an equal partnership of professional and lay members. The aim is to ensure that purely professional concerns do not dominate the proceedings, and to dispel the notion that regulators are overly sympathetic to the medical profession.

According to Scott, self-regulation, has served patients and the public well but is no longer credible, and no such scheme would command public or political support in today's climate.

Under the proposal, doctors will have to revalidate their license to practise every 5 years to meet standards set and assessed by the Royal Colleges. The Royal College of Physicians says it welcomes this role in setting clinical standards for medical practice. "We have decades of experience to draw on, and have been in the forefront of developing new methods of continuing assessment for doctors," says its President, Professor Ian Gilmore.

The proposed changes will also alter the onus of proof at disciplinary hearings from the criminal standard, wherein facts must be proven beyond reasonable doubt, to a civil standard that requires that the facts be judged more likely than not to be true. The latter is already employed by most health regulators. A Department of Health spokesman explains that "The public are unable to understand why a disciplinary hearing by a National Health Services employer can find a practitioner guilty of misconduct but the regulatory body then states that there is not enough high quality evidence for a hearing to consider their registration."

Scott made it clear that for the most serious matters, such as those that could lead to loss of registration, the effect of the civil standard of proof will, in practise, be close to the existing criminal standard.

The British Medical Association has concerns with the proposal. "Removal of the adjudication function from the GMC, having appointed GMC Council members instead of elected doctors, lay and medical members, and the switch to a lesser burden of proof for fitness to practice, all add up to a loss of professionally led regulation." However, a Department of Health spokesman emphasized that the new system will be predominantly professionally led, with doctors carrying out appraisal, setting and assessing standards, and sitting on the adjudicating panels.

The GMC hopes the plans for professional and lay regulatory bodies will be implemented in the latter half of 2008 , along with the move to the civil standard of proof. This will be followed by pilot revalidation schemes in 2009, with full implementation during the following year.

In Canada, the President of the Federation of Medical Regulatory Authorities, François Gauthier, says that like the proposed UK system, "all Canadian jurisdictions have public or non-physician representatives, and in several cases, some or all of these are government appointees." - Cathel Kerr, Fife, Scotland

DOI:I0.I503/cmaj.07043I

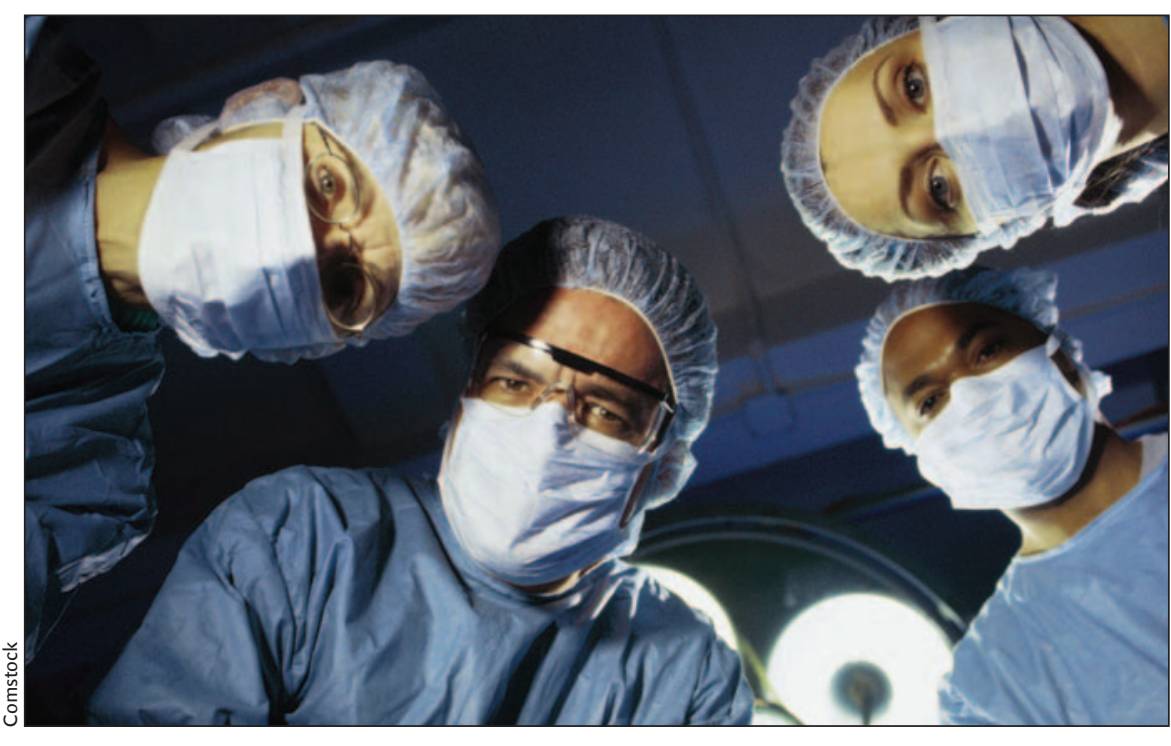

The UK's General Medical Council says self-regulation is no longer a credible option. 